\title{
Prevalence of Corynosoma caspicum infection in Gasterosteus aculeatus fish in Caspian Sea, Northern Iran
}

\author{
Bahman Rahimi-Esboei ${ }^{1}$, Mahdi Najm², Morad Shaker ${ }^{3}$, Mahdi Fakhar ${ }^{4}$ and Iraj Mobedi ${ }^{1}$
}

1. Department of Parasitology and Mycology, School of Public Health and Health Research Institute, Tehran University of Medical Sciences, Tehran, Iran; 2. Department of Parasitology, Student Research Committee, School of Medicine, Iran University of Medical Sciences, Tehran, Iran; 3. Department of Fisheries, Islamic Azad University, Babol Branch, Babol, Iran; 4. Department of Parasitology, Molecular and Cell Biology Research Center, School of Medicine, Mazandaran University of Medical Sciences, Sari, Iran.

Corresponding author: Mahdi Fakhar, e-mail: mahdif53@yahoo.com

Co-authors: BRE: bahman5164@yahoo.com, MN: mehdi.najm1@yahoo.com, MS: morad.aquatic@gmail.com, IM: mobedii@yahoo.com

Received: 31-05-2017, Accepted: 05-09-2017, Published online: 27-09-2017

doi: 10.14202/vetworld.2017.1139-1142 How to cite this article: Rahimi-Esboei $B$, Najm M, Shaker M, Fakhar M, Mobedi I (2017) Prevalence of Corynosoma caspicum infection in Gasterosteus aculeatus fish in Caspian Sea, Northern Iran, Veterinary World, 10(9): 1139-1142.

\begin{abstract}
Aim: There is little information about the prevalence of Corynosoma caspicum in fish particularly Gasterosteus aculeatus in Iran and the world. The aim of the present study was to find out the prevalence of acanthocephalan infection in Babolsar district, southern coastal of Caspian Sea, Northern Iran.
\end{abstract}

Materials and Methods: Between September 2012 and August 2014, a total of 360 G. aculeatus fishes were randomly collected by drift nets from coastal regions in Babolsar and then examined the intestine and body cavity for worm infections.

Results: A total of 360 G. aculeatus fishes, 109 (30.3\%) were found infected with at least one Corynosoma capsicum, and there was no significant association between genders and the prevalence infection of acanthocephalan. Moreover, there was a significant difference in infected rate between summer $(79 \%, 86 / 109)$ and spring $(21 \%, 23 / 109)(\mathrm{p}<0.05)$.

Conclusion: The high occurrence of Corynosoma infection in G. aculeatus indicates the enzootic constancy status of the infection in the southern coastal of Caspian Sea, Northern Iran.

Keywords: Acanthocephalosis, Caspian Sea, Corynosoma caspicum, Gasterosteus aculeatus.

\section{Introduction}

Acanthocephala is a phylum of parasitic worms known as acanthocephala, and the phylum is included in four classes - Palaeacanthocephala, Archiacanthocephala, Polyacanthocephala, and Eoacanthocephala [1]. Thorny-headed worm or spinyheaded worms have variable length from $6 \mathrm{~mm}$ to $30 \mathrm{~cm}$. Proboscis is retractable into the body; body covered with tegument and spines and absorbs the nutrients. Its life cycle routinely requires only one intermediate host, such as cyclops or brine shrimp [2]. Acanthocephalans can infect a number of hosts including fishes, amphibians, birds, and mammals as final hosts. Some species of acanthocephalans (known as the perforating acanthocephalan) can pierce their proboscis in the gut wall of the host and go through to the peritoneal cavity [3]. To date, about 1150 species of acanthocephalans have been described by Cleave [4].

Gasterosteus aculeatus is a kind of three spine sticklebacks; these fishes have three dorsal spines,

Copyright: Rahimi-Esboei, et al. Open Access. This article is distributed under the terms of the Creative Commons Attribution 4.0 International License (http://creativecommons.org/licenses/ by/4.0/), which permits unrestricted use, distribution, and reproduction in any medium, provided you give appropriate credit to the original author(s) and the source, provide a link to the Creative Commons license, and indicate if changes were made. The Creative Commons Public Domain Dedication waiver (http:// creativecommons.org/publicdomain/zero/1.0/) applies to the data made available in this article, unless otherwise stated. two pelvic spines, and one anal spine [5]. It is common in slow-moving backwaters of rivers, lakes, ponds, sheltered bays, and harbors with a worldwide distribution in coastal marine and fresh water of the northern hemisphere [6]. Corynosoma caspicum belongs to the class of Palaeacanthocephala [7], order of Polymorphida [8], family of Polymorphidae [7], and genus and species of C. caspicum [8]. Recently, a comprehensive list relating to the acanthocephalan fauna of Iran has been reported. In total, 30 known species of acanthocephala from 21 genera, 12 families, and 7 orders were reported from 80 species of various vertebrates in Iran [9]. Species identification of acanthocephalans is mostly based on morphological features, including the size and number of hooks on the proboscis and the number of spines on the body surface $[3,4]$.

Although Corynosoma strumosum and Bolbosoma caenoforme have been previously reported in the G. aculeatus fish from north of Iran [10,11], C. caspicum has been reported from different fish species except $G$. aculeatus fish. In fact, little information is available regarding prevalence and density of C. caspicum among fishes in Iran and around the world principally Caspian Sea littoral countries. Thus, the aim of the present study was to determine the prevalence and intensity of acanthocephalan infections, in G. aculeatus fishes in the Southern part of the Caspian Sea. 


\section{Materials and Methods}

\section{Ethical approval}

During all stages of our research, all applicable international, national, and/or institutional guidelines for the care and use of animals were followed. The fishes were caught according to the ethical approval of the Caspian Sea Ecology Research Center.

\section{Study area}

Between 2012 and 2014, the present study was conducted in southern coastal of Caspian Sea, Mazandaran Province $\left(53^{\circ} 6^{\prime} 5 \mathrm{E}, 3^{\circ} 23^{\prime} 3 \mathrm{~N}\right)$. This province has a moist and temperate weather with an average annual rainfall of about $1000 \mathrm{~mm}$ [12].

\section{Fish collection and biometric measuring}

In this study, $360 \mathrm{G}$. aculeatus fish samples were collected by fishermen, using drift nets with $5 \mathrm{~mm}$ mesh size, during September 2012-August 2014 in coastal Caspian Sea in Babolsar district, Northern Iran. After being caught, the fishes were frozen at $-20^{\circ} \mathrm{C}$ and transported to the Caspian Sea Ecology Research Center Laboratory, and biometric features such as total length, standard length, and sex for each fish were measured [2].

\section{Fish examination for the acanthocephala}

The fish samples were subsequently dissected, and the lumen of the intestine of them was examined for acanthocephalan parasites and then morphological features using a stereomicroscope with several magnifications. At first, collected acanthocephalans were washed in normal saline solution, irrigated in water to emerge the proboscis overnight. Later, the worms were fixed in alcohol/formalin/acetic acid fixative, preserved in $70 \%$ ethanol until processed for identification. Next, they were cleared with lacto phenol and then stained with azocarmine stain. Morphological and morphometric characteristics for every specimen were drawn by camera lucida, at $400 \times$ magnification and characterization were confirmed based on key references $[13,14]$; in addition, the parasite specimens were sent to Iranian Parasitology National Museum (IPNM) at Veterinary School of Tehran University for species confirmation. Our study was a descriptive cross-sectional study; hence, a negative control was not included.

\section{Results}

A total of 360 G. aculeatus caught, 109 (30.3\%) were infected for acanthocephalan throughout September 2012-August 2014. In total, 67\% (73/109) and $33 \%(36 / 109)$ of the infected fishes were female and male, respectively. No significant difference between gender and the prevalence of acanthocephalan was observed $(\mathrm{p}>0.05)$. In general, 192 fishes were caught in spring, and 168 ones were caught in summer, and there was a significant difference in infected rate between summer $(79 \%, 86 / 109)$ and spring $(21 \%, 23 / 109)(\mathrm{p}<0.05)$.

Moreover, fish biometrical features showed the length mean \pm standard deviation (SD) was the
$6 \pm 0.38 \mathrm{~cm}$ (Figure-1). No significant relationship was observed between fish size and the infection rate of acanthocephalan $(\mathrm{p}>0.05)$. The adult worms were found to be in the lumen of the intestine, and the majority of them attached to the intestinal mucosa though some in the peritoneal cavity. In addition, 24 out of $109(22 \%)$ had numerous infections with more than two worm.

Morphological features of the isolated adult acanthocephalan were as follow: The length mean \pm SD of adults was $4.3 \pm 2.7$. The body comprises an anterior proboscis, a neck (presoma), and a trunk (metasoma) (Figure-2). There were 16-18 longitudinal rows of hooks and 10-11 hooks per row on the proboscis. The average size of hooks on proboscis was $5.96 \mu \mathrm{m}$ and hooks on trunk were $2.73 \mu \mathrm{m}$. The end of posterior cone of the worms' body was covered with five to six (mostly six) rows of spines. Based on these

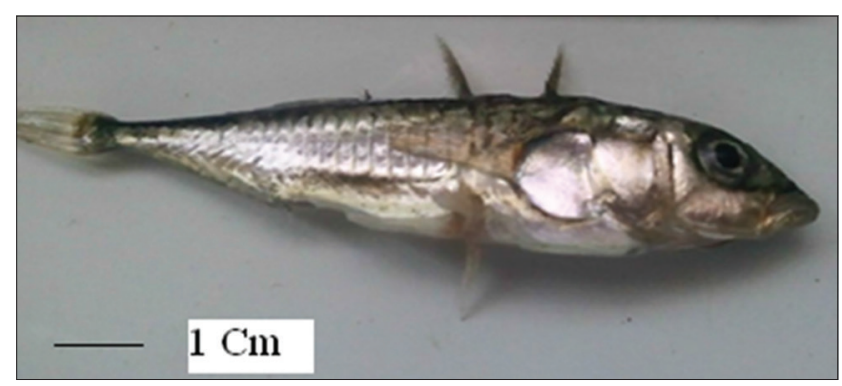

Figure-1: A male Gasterosteus aculeatus fish infected with Corynosoma caspicus from Caspian Sea; Note the dorsal spines on the body (scale bar: $1 \mathrm{~cm}$ ).

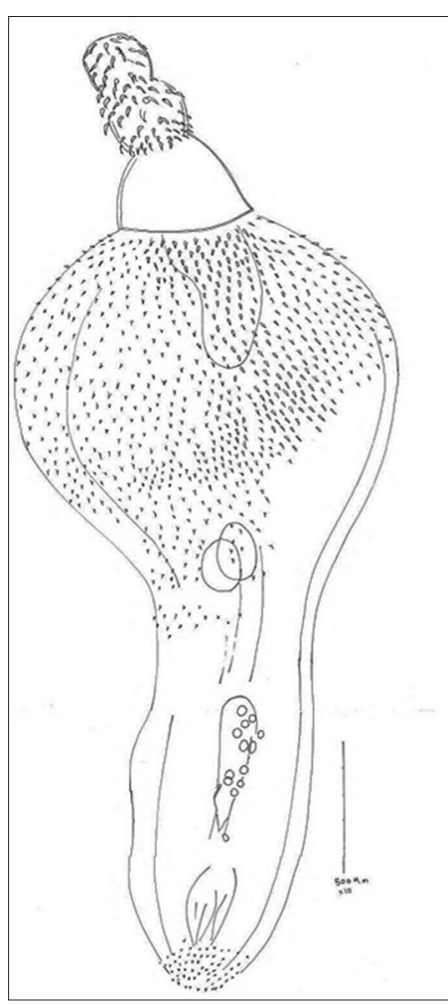

Figure-2: An adult male of Corynosoma capsicum showing anterior proboscis with longitudinal rows of hooks and the posterior proboscis with spines (scale bar: $500 \mu \mathrm{m}$ ). 
morphological details and the IPNM report $[13,14]$, all specimens were identified as $C$. caspicum.

\section{Discussion}

Lake fish parasites have received little notice in Iran; however, few studies have been performed in the recent years. In our study, for the first time, we found the high infection rate $(30.3 \%)$ of $C$. caspicum in exotic G. aculeatus fish in coastal Caspian Sea, Northern Iran. The acanthocephalans parasites frequently cause intestinal perforation throughout heavy infected condition.

In this study, there was no significant difference between fish size and the prevalence of acanthocephalan. However, Amin et al. (2013) reported the prevalence of infection decreased with increasing fish size in case of Acanthogyrus (Acanthosentis) barmeshoori collected from the Persian tooth-carp, in Southern Iran. However, it seems that the relationship between prevalence of infection rate and size of fishes depends on species of fish and also acanthocephalans genera, although it remains controversial $[15,16]$. In general, there are no data in this view.

Furthermore, in our study, there is a significant difference between infection rate of $C$. caspicum and season. Seasonally, the prevalence of infection increased to $79 \%$ during summer season and decreased to $21 \%$ during spring; which our finding is in concurrence with the findings of comparable investigations [17]. However, little information is available on this subject in literature.

Although acanthocephalan infections are common in various regions of the world particularly marine sea; however, the prevalence rate of C. caspicum in fish is mainly unknown in Iran. Several studies have been conducted on fish parasites in the Caspian Sea [18-22]. In Iran, also, several researchers have been investigated the parasitic infections in fishes in Southern coastal of Caspian Sea [10,23-29], but there is little information concerning Corynosoma spp. in various species of fish.

In Iran, the majority of reports concerning acanthocephalan infection, in particular, Corynosoma spp. belongs to edible fishes such as Clupeonella cultriventris and Acipenser stellatus as sea food throughout food chain $[28,30]$. However, there is little investigation on the prevalence of parasitic infections in the G. aculeatus, as non-suitable for eating fishes, in Iran and the world.

The results of the present study showed that acanthocephalan infections are notably more common (30.3\%) in Caspian Sea in comparison with Persian Gulf. C. strumosum has already been reported from Acipenseridae, Neogobiidae, and Clupeidae in various areas of Iran [10,28,30,31].

\section{Conclusions}

The high prevalence and intensity of Corynosoma infection in $G$. aculeatus demonstrate the enzootic situation of marine fish acathocephalosis in the southern coastal of Caspian Sea, Northern Iran; therefore, it needs a basic push to decrease the rate of infection conceivably by natural control in the future such as control of other marine pests. However, each acanthocephalan species can possibly have a capable effect on its ecosystem by ideals of its impacts on its host species at each level. As a whole, our preliminary study recommended further and broad explorations on the brine shrimp and or cyclops, as intermediate host, and also other fish species, waterfowls and sea seal, as final host, in several regions of coastal Caspian Sea. Moreover, further investigation on the morphology of C. caspicum using scanning electron microscopy is recommended in future.

\section{Authors' Contributions}

MF designed all steps of the study. BRE, MS, and $\mathrm{MN}$ collected samples of fish and examined throughout the study. IM illustrated Figure-2 and characterized the morphology of Corynosoma. MS characterized the G. aculeatus fish. MN took a photo from the G. aculeatus fish (Figure-1). MF and BRE prepared the tables of results and discussed it. BRE wrote the manuscript draft, and all authors have read, revised, and approved the final draft.

\section{Acknowledgments}

The authors are grateful to express their thanks to Vice-Chancellor for Research and Technology of Mazandaran University of Medical Sciences for financial support (no. 91-114).

\section{Competing Interests}

The authors declare that they have no competing interests.

\section{References}

1. Hyman, L. (1951) The Invertebrates: Acanthocephala, Aschelminthes, and Entoprocta. McGraw Hill, New York. p459-531.

2. Nachev, M. and Sures, B. (2009) The endohelminth fauna of barbel (Barbus barbus) correlates with water quality of the Danube in Bulgaria. Parasitology, 136: 545-552.

3. Muller, R. (2012) Worms and Human Disease. CHBI Publishing, UK.

4. Cleave, H. (1952) Speciation and formation of Genera in Acanthocephalan. System Zoolo., 1(2): 245-249.

5. Barnes, R. (1980) Invertebrate Zoology. Saunders Company, Philadelphia, PA. p309-311.

6. Coad, B.W. (1992) A checklist and bibliography. Ichthyology section. Freshwater Fishes of Iran. Canadian Museum of Nature, Ottawa, Ontario, Canada. p66.

7. Meyer, A. (1932) Acanthocephala. In: Bronn's Klassen, H.G., editor. Ordnungen Des Tierreichs. Vol. 4. Akademische Verlagsgesellschaft MBH, Leipzig. p1-332.

8. Golvan, Y. and Mokhayer, B. (1973) Corynosoma capsicum. Available from: http://www.marinespecies.org/aphia. php? $\mathrm{p}=$ taxdetails\&id=448856. Accessed on 02-12-2014.

9. Tavakol, S., Amin, O.M., Luus-Powell, W.J. and Halajian, A. (2015) The Acanthocephalan fauna of Iran, a check list. Zootaxa, 4033(2): 237-258.

10. Niksirat, H., Hatef, A., Hajmoradloo, A.M., Ghorbani, R. and Nikoo, M. (2012) Infection of three-spined stickledback 
Gasterosteous aculeatus (L.) with Corynosoma strumosum in gomishan lagoon. J. Iran. Fish. Sci., 15: 155-160.

11. Hosseinifard, S.M., Youssefi, M.R., Hoseini, S.H. and Mobedi, I. (2012) First report of the Acanthocephalan, Bolbosoma caenoforme (Heitz, 1920), in the Gasterosteus aculeatus fish from north of Iran. World. J. Zoolo., 5(4), 264-265.

12. Mahjouri, E. (2013) Historical Geography of Mazandaran Province. Geographical Organization Press, Tehran, Iran.

13. Yamaguti, S. (1971) Systema Helminthum. Vol. 3. Interscience Publishers Inc, New York, USA. p612-614.

14. Amin, O.M. (2013) Classification of the Acanthocephala. Folia Parasitol., 60(4): 273-305.

15. Amin, O.M., Gholami, Z., Akhlaghi, M. and Heckmann R.A. (2013) The description and host-parasite relationships of a new Quadrigyrid Species (Acanthocephala) from the Persian Tooth-Carp, Aphanius farsicus (Actinoptreygii: Cyprinodontidae) in Iran. J. Parasitol., 99: 257-263.

16. Jithendran, K.P. and Kannappan, S. (2014) A short note on heavy infection of Acanthocephalan worm (Neoechinorhynchus agilis) in grey mullet, Mugil cephalus. J. Parasit. Dis., 34(2): 99-101.

17. Abdel-Ghaffar, F., Morsy, K., Abdel-Gaber, R., Mehlhorn, H., Al-Quraishy, S. and Mohammed, S. (2014) Prevalence, morphology, and molecular analysis of Serrasentis sagittifer (Acanthocephala: Palaeacanthocephala: Rhadinorhynchidae), a parasite of the gilthead sea bream Sparus aurata (Sparidae). Parasitol. Res., 113: 2445-2454.

18. Bykhovskaya-Pavlovskaya, I.E., Gussev, A.V., Dubinina, M.N., Izyumova, N.A, Smirnova, T.S., Sokolovskaya, A.L., Shtein, G.A. and Shul'man, S.S. (1962) Key to parasites of freshwater fishes of the U.S.S.R. Publication House of the V.S.S.R. Academy of Sciences, Moscow-Leningrad. p776.

19. Lomaki, V.V. (1970) Distribution and some question of the biology of Cucullanllusminutus (Nematode: Camallanata) in fishes of the Caspian Sea. Voprosy Morskoy Parazitol., pp: 68-69.

20. Gibson, D.I. (1972) Contributions to the life-histories and development of Cucullanusminutus rudolphi, 1819 and $C$ heterochrous rudolph: 1802 (Nematoda: Ascaridata). Bull. Br. Mus. Nat. His. Zoolo., 22: 153-170.

21. Gussev, A.V. (1985) Parasitic metazoan, class - Monogenidae. In: Bauer, O.N., editor. Key to the Parasites of Freshwater Fish of the USSR. Vol. 2. Nauka, Leningrad.

22. Mikailov, T.K. (1975) Parasite fauna of fishes of the basins of Azerbaidzhan. Izd. Elm, Baku., pp: 299.

23. Mokhayer, B. and Anwar, M. (1973) Effect pathogen des parasites de l'esturgeondans le milieu natural et artificial. Rivista italiana. Di. Piascicolotura. Ed Ittiopatologia, 4: 111-115.

24. Eslami, A. and Kohneshahri, M. (1978) Study on the helminthiasis of Rutilus frisiikattum from south Caspian Sea. Acta Zoolo. Pathol. Antverp., 70: 153-155.

25. Mokhayer, B. (1983) Parasites and Parasitic Diseases of Fish. The $5^{\text {th }}$ International Symposium of Ichthyoparasitology, Ceske Budejovice. p8-13.

26. Ghoroghi, A. and Pougholam, R. (1996) Identification of the parasitic diseases of huso huso. J. Pajouhesh Sazandegi., 28: $12-15$.

27. Pazooki, J. and Masoumian, M. (2012) Nematode Parasites from some freshwater fishes of Gyilan Mazandaran Provinces. J. Pajouhesh Sazandegi., 51: 93-99.

28. Sattari, M., Shafii, S.H., Daghigh-Rouhi, J., Bourbiria, H. and Najest, N. (2013) Survey on Eustrongilides larvae in some fishes of the Caspian Sea. J. Vet. Med. Fac., 57: 1.

29. Khara, H., Sattari, M., NezamiSh, A., Mosawi, S.A. and Jaafarzadeh, E. (2015) Survey on prevalence and intensity parasitic infection Esox lucius from Amir-Kolateh, Lahijan. J. Vet. Fac., 57(4): 333-340.

30. Daghigh-Rouhi, J. and Sattari, M. (2014) Survey on incidence of parasitic infection in the Gobiidae fishes from South-Western part of the Caspian Sea. J. Vet. Med. Fac., 59(1): 22-27.

31. Sattari, M. and Mokhayer, B. (2005) Occurrence and intensity of some parasites in five sturgeon species (Chondrostei: Acipenseridae) southwest of Caspian Sea. Curr. Sci., 89: $259-263$

$* * * * * * * *$ 